Policy Research Working Paper 1475

Decentralization

The Way Forward for Rural Development?

\author{
Andrew N. Parker
}

\author{
Alnough te \\ initiatives na: \\ much ine: \\ understog \\ comporiw: : \\ decentraliz: \\ advice ar: \\ policymen:-
}

The World Bank

Agriculture and Natural Resources Department Sector Policy and Water Resources Division June 1995 


\section{Summary findings}

Special strategies are needed to address the widespread incidence of rural poverty in developing countries, but iniriatives aimed at improving the rural standard of living have nut consistently reduced poverty.

Parker examines the rationale for a specific rural focus in poverty reduction programs and reviews recent attempts to encourage rural development. He discusses the role decentralization could play in rural development programs and analyzes recent efforts to implement decentralized rural development programs.

Parker concludes that although decentralization initiatives have a long history, much more needs to be understood about various components of decentralization before sound advice can be given to policymakers.

He suggests a conceptual model - based on a "souffle" theory of decentralization - that incorporates the essential elements of political, fiscal, and institutional decentralization as they relate to rural development outcomes.

Like a souffle that requires just the right combination of atik, eggs, and heat to rise, a successful program of decentralization must include just the right combination of political, fiscal, and institutional elements to improve rural development outcomes.

This paper - a product of the Sector Policy and Water Resources Division, Agriculture and Natural Resources Department - is part of a larger effort in the department to develop a new strategy for rural development. The study was partly funded by the Bank's Research Support Budget under the research project "Decentralization, Fiscal Systems, and Rural Development" (RPO 679-68). Copies of this paper are available free from the World Bank, $1818 \mathrm{HStreet} \mathrm{NW,} \mathrm{Washington,}$ DC 20433. Please contact Dean Housden, room N8-057, extension 36637 (52 pages). June 1995.

The Policy Research Working Paper Series disseminates the findings of work in progress to encourage the exchange of ideas about development issues. An objective of the series is to get the findings out quickly, even if the presentations are less than fully polished. The papers carry the names of the authors and should be used and cited accordingly. The findings, interpretations, and conclusions are the authors' oun and should not be attributed to the World Bank, its Executive Board of Directors, or any of its member countries.

Produced by the Policy Research Dissemination Center 


\title{
DECENTRALIZATION: \\ THE WAY FORWARD FOR RURAL DEVELOPMENT? ${ }^{1}$
}

\author{
Andrew N. Parker ${ }^{2}$
}

1 This paper-a product of the Agriculture and Natural Resources Department-is part of a larger research study in the Department to develop a new strategy for rural development. The research study is jointly funded by the Norwegian and Swiss Special Studies Trust Funds and by the Bank's Research Support Budget under the project "Decentralization, Fiscal Systems and Rural Development" (RPO 679-68). Copies of this paper are available free from the World Bank, $1818 \mathrm{H}$ Street NW, Washington DC 20433. Please contact Dean Housden, room N 8057, extension 36637 (52 pages).

2 I am grateful to Hans Binswanger, Klaus Deininger and Johan van Zyl for comments on earlier drafts of this paper. 


\section{CONTENTS}

Characteristics of Rural Areas 2

Urban Bias 2

Excessive Agricultural Taxation ___ 4

Inadequate Resource Mobilization___ 6

Political Economy ___ 8

Strategies for Rural Development 12

Integrated Rural Development ___ 12

Failure of Integrated Rural Development __ 14

New Opportunities for Rural Development___ 17

Decentralization 18

Defining Decentralization ___ 19

Political Decentralization ___ 23

Fiscal Decentralization ___ 28

Institutional Decentralization 32

Decentralized Rural Development

Sectoral Decentralization __ 37

Recent Experience from Latin America __ 39

Conclusions___ 43

Conceptual Framework __ 43

Further Research ___ 45

References 

Poverty continues to pervade rural areas in developing countries ${ }^{1}$. Inappropriate public policies and ill-designed programs and projects have both served to impoverish rural communities. As reviewed later in this paper, trade and fiscal policies have often discriminated against agriculture. Public expenditure allocations for agriculture are often inadequate and frequently misdirected, providing perverse incentives to producers in the form of tax and subsidy programs. In addition, recent research has demonstrated the overriding importance of a stable macroeconomic environment. The best-designed policies for rural development (RD) are likely to fail if a country faces severe macroeconomic imbalances ${ }^{2}$.

Despite recognition of the need for special strategies to address the widespread incidence of rural poverty in developing countries, initiatives aimed at bringing about a transformation of the rural standard of living have not had a consistent impact on reducing poverty. The failure of the most recent of these interventionsintegrated rural development (IRD) - has left a policy vacuum as donors and countries struggle to find new ways to reduce rural poverty. Recent initiatives designed to put in place decentralized mechanisms for $\mathrm{RD}$ offer possibilities for building on the essential principles of IRD while avoiding problems associated with an over-centralization of functions and responsibilities.

This review examines the rationale for a specific rural focus and reviews recent attempts to encourage $\mathrm{RD}$. The potential role for decentralization to play in designing improved RD programs is discussed, and some of the recent efforts to implement programs of decentralized RD are described and analyzed.

The article concludes that although decentralization initiatives have a long history, much more needs to be understood with respect to the various components of decentralization if sound advice is to be given to policy-makers. A conceptual model is suggested that incorporates the essential elements of decentralization processes and relates them to RD outcomes. 


\section{Characteristics of RuRal AREaS}

The spatial dispersion of people living in rural areas increases the cost and difficulty of providing rural goods and services effectively. Specific economic conditions in rural areas also result in fewer development opportunities being available than in non-rural locations. Agriculture is generally the most important economic sector, making rural areas highly dependent on the performance of a single sector, where investments are risky. In addition, the tax base is limited, resulting in rural areas often being unable to mobilize sufficient resources to finance their own RD programs.

Furthermore, rural areas are often politically marginalized, leaving little opportunity for the rural poor to influence government policies. In many developing countries, policies have consistently discriminated against agriculture through high levels of taxation and other macroeconomic policies that have adversely affected agricultural performance and the rural tax base, resulting in a net transfer of resources out of rural areas.

The impact of this combination of geographic, economic and political factors is a high incidence of poverty and a low level of development, as measured by indicators such as rates of literacy, life expectancy, infant mortality and malnutrition. A description and explanation of this discrimination against agriculture and rural areas has been given in the urban bias literature.

\section{Urban Bias}

In his seminal work on urban bias, Lipton (1977) maintains that urban elites, by organizing, centralizing and controlling political and economic power, have been able to control substantially policies and the distribution of resources in poor developing countries. He argues that despite historically high levels of economic growth, the proportion of rural people living below a fixed acceptable standard has not fallen much. He further attributes this to a deliberate misallocation of resources between rural and urban areas. He seeks to demonstrate that: 
"many of the resources allocated by state action to city-dwellers would have earned a higher return in rural areas; that private individuals, furthermore, were indirectly induced by administrative decisions and price distortions to transfer from countryside to town their own resources, thereby reducing the social (but increasing the private) rate of return upon those as well; and that, ultimately, inadequate inputs of rural resources substantially reduced even the efficient use of urban resources" (Lipton 1977: 70-1).

Though far more numerous than urban populations, rural people are more dispersed, poor, inarticulate and disorganized. The result is an allocation of resources between urban and rural areas that is unfairly biased against rural areas and is economically inefficient. For example, on average in developing countries the agriculture sector employs 70 percent of the labor force and generates between 40 45 percent of GNP, yet it receives less than 20 percent of public investment and has been induced or forced to contribute considerably more to public savings through high levels of taxation.

Lipton, takes the debate one step further and argues that an "urban alliance" is forged between urban and rural elites that explains much of the inequality within rural areas. It is only the better-off farmers, who produce in excess of their consumption needs and therefore have surpluses available for transfer to urban centers. They often benefit from compensating transfers, in the form of price support and production subsidies for fertilizer and credit. The implication of this alliance is that surpluses that would otherwise have been available for local RD investments are consumed by rural elites or transferred to urban centers, further impoverishing the rural poor.

The concomitant lack of investment in rural areas that is the result of the surplus transfers to cities is manifested in the low level of services provided to the rural poor. The general tendency within rural areas is for services to be concentrated in local government administrative centers, and for outlying villages to have to accept either nonexistent services-no schools, health posts or extension 
agents, or a level of service that is wholly inadequate-excessive travel times to reach school, infrequent visits by extension agents.

A special issue of the Journal of Development Studies (Varshney 1993) reconsidered the question of urban bias. Contributing authors argued that there are conditions under which urban bias might be eroded, and several country examples were cited, e.g., an increase in the variety of political institutions offers the possibility for rural interests to be represented under competitive party systems (India, Costa Rica); technical change through sustained growth in agriculture may begin to make the rural sector more powerful, as its contribution to economic growth expands (Côte d'Ivoire, Cuba, Costa Rica, China, India); ethnic, religious and other class identities may cut across the rural-urban divide (South Korea, Taiwan, India).

It is clear that under certain specific conditions, particular elements of urban bias may decline, and rural forces may even be successful in securing a redirection of resources to rural areas, e.g., in Indonesia where a significant number of farmers have benefited from public resource allocations. Nevertheless, as Lipton (1993) points out in a rejoinder article, specific examples taken out of context do not prove that the rural sector has ceased being discriminated against, and if a wider definition of urban bias is considered there is clear evidence of the tendency for urban bias to continue to exist.

\section{Excessive Agricultural Taxation}

Incentive policies have been analyzed in a five-volume series, summarized in Schiff and Valdés (1992). They examine the impact of trade and pricing interventions on agricultural incentives in eighteen developing countries between 1960-85. They found that discrimination-in the form of overvalued exchange rates, industrial protection and direct intervention in the agriculture sector-adversely affected both agricultural growth and overall economic development.

Schiff and Valdés present a detailed exposition of the particular types of policies utilized by governments to discriminate against agriculture. This analysis leads to the following conclusions: 
- All but two of the countries surveyed (Republic of Korea and Portugal) taxed their agricultural sectors during the period studied. Taxation was most severe, ranging from 45-60 percent, in the three African countries sampledCôte d'Ivoire, Ghana and Zambia; it was moderately severe ( $25-45$ percent) in Argentina, Colombia, Dominican Republic, Egypt, Morocco, Pakistan, Philippines, Sri Lanka, Thailand and Turkey; and it was relatively low (8-22 percent) in Brazil, Chile and Malaysia;

- On average, three-quarters of agricultural taxation derived from indirect measures, mainly overvalued exchange rates and industrial protection; only one-quarter derived from direct agricultural policy measures.

- Direct interventions generally protected food crops without comparative advantage, e.g., wheat in Brazil, and negatively protected export commodities with a large comparative advantage, e.g., rice in Thailand, cotton in Egypt, coffee and cocoa in West Africa and Latin America. The combined negative impact of direct and indirect interventions are likely to have severely depressed private agricultural investment and economic growth ${ }^{3}$;

- Public investment in agriculture and subsidies for agricultural inputs aim to provide compensation for the negative impact of government interventions. However, whether by design or by properties inherent in the instruments chosen (e.g., credit and other production subsidies), such interventions tended to benefit large farmers and "did not compensate, or compensated very little, for the substantial income outflows resulting from interventions in output markets ${ }^{4}$, and in most cases, public investment in agriculture did not compensate for the negative effects of price interventions...In sum: government and the nonagricultural sectors were the winners in most cases, and agriculture the loser" (Schiff and Valdés: 8); and

- Differential protection and negative protection of individual commodities led to significant reallocations within the agricultural sector that were not in 
line with the governments' proclaimed aims of food security and poverty reduction. While revenues were raised and prices stabilized, highly inefficient instruments of intervention were chosen that were not costeffective.

The ideological rationale for high rates of agricultural taxation was grounded in the widely-held view that the best way to accelerate economic growth was through urban growth and encouragement of rural-urban migration. These views have been thoroughly discredited and many developing countries have reduced levels of agricultural taxation. Nevertheless, rural areas still face the challenge of mobilizing sufficient resources to fund the components of RD.

\section{Inadequate Resource Mobilization}

It is difficult to mobilize sufficient resources in rural areas to finance the components of RD. Raising taxes is more difficult in rural than urban locations, because taxation reduces already low levels of rural income. Even where this is not the case, the tax base is usually small. Also, due to a higher level of self-sufficiency in rural communities, trade in taxable goods and services is often limited.

In any case, most of the taxes proposed for rural areas do not possess the desirable characteristics of an appropriate local tax as identified in the optimal taxation literature. Bird and Wallich (1993) have argued that a local tax should be characterized by: (i) the presence of a fixed tax base to permit location-specific variation in tax rates; (ii) a visible tax base to ensure accountability; (iii) a perception of the tax as being fair; (iv) stable tax yields that are not eroded by inflation; and (v) tax revenues that are adequate to meet needs as they expand. Despite these difficulties, efforts have been made to raise rural taxes. Three main types of taxes have been used:

Agricultural Commodity Taxes. In the second half of the twentieth century, export taxes on agricultural commodities have been the single most important source of government revenue from agriculture and rural areas. As noted in the Schiff and Valdés (1992) study, commodity taxes contributed an average of ten 
percent of government spending between 1960-85. The revenues from export taxes accrued to central governments, however, resulting in rural communities at best receiving only limited direct benefit from the product of their own labor, and often receiving no benefit at all.

Realizing the negative incentive effects that export taxes have on agricultural producers, developing country governments have tended to reduce levels of export tax over the past few years. These types of agricultural taxes are, therefore, unlikely to provide a significant contribution to overall revenues in the future.

Agricultural Land Taxes. Binswanger et al (1993) summarize three main advantages that a land tax has over a tax on agricultural output or exports: (i) it has minimal disincentive effects if the tax is based on the potential monetary yield of a certain plot under normal conditions; (ii) it facilitates taxation of the domestic subsistence sector, while being much less regressive than a poll tax; and (iii) provided the tax base is not changed too frequently, a land tax will not discourage investment in land improvements.

Although land-based taxes are considered to be the highest-yielding tax instruments available to local governments, nowhere in the world have land and property taxes, in both rural and urban areas, taken together contributed more than ten percent of total tax revenue (Bird and Wallich 1993). Administering land taxes effectively and equitably requires detailed information on land size, value, ownership, and its productive capacity. Even in the few developing countries that maintain a sufficiently detailed cadastral survey, land taxes are relatively unimportant. Often associated with previous extractive colonial or military regimes, rural land taxes typically incur high political costs that offset any revenue gains. Developing-country governments are therefore unlikely to turn to land taxes as a major source of revenue for rural areas.

User Charges and Fees. The use of user charges and fees as potential sources of additional local resources has received considerable recent attention (Bahl and Linn 1992), not so much as mechanisms to boost overall local revenues, but to 
earmark revenues to ensure a sufficient level of resources is available to finance at least the operation and maintenance $(O \& M)$ costs of infrastructure projects, and preferably the capital costs also.

In Indonesia, for example, important reforms of health service pricing have been initiated (Shah and Qureshi 1994). Fees for health services have been doubled in some districts, and rather than a fall in service utilization because of higher prices, utilization has risen in response to better service delivery. As a result some districts are now fully covering their O\&M costs.

At the village level the contribution of user charges and fees to revenues could be significant, and there is evidence that fees could be increased in many developing countries (Bahl and Linn 1992). Nevertheless, it is unlikely that these fees would be sufficient to make a significant increase in the overall level of resources available to rural communities.

Rural areas, thus, face a dual problem of having an insufficient resource base to generate resources, while, at the same time, having to meet excessive levels of taxation levied by central governments. Although the literature on optimal taxation and urban bias provide a basis for understanding why agricultural growth has been stifled and rural poverty remains pervasive, no explanation has been given as to the motivation of urban elites nor the mechanisms used by them to maintain their dominance, i.e., the political economy of rural areas is not considered.

\section{Political Economy}

Rural and urban interests in developing countries are articulated differently through the political process. Binswanger and Deininger (1995) note the difficulty faced by rural communities in organizing for collective action. Olson (1971) suggests three factors in particular that may contribute to the low ability of rural populations in developing countries to articulate their political demands.

First, together with the ability to overcome the free-rider problem and enforce rules, the cost of organization and communication determine the "pressure" function of different groups in an otherwise undistorted, perfect-information and risk-free 
environment. Spatial dispersion, heterogeneity, and lack of policing and enforcement capacity reduce the efficiency of pressure production in rural areas in developing countries. Note that the highly concentrated production of specific agricultural commodities may provide a good opportunity for farmers in developed countries to increase their political voice (Olson 1985$)^{5}$.

Second, any redistribution of income will be resisted by losers. Under the assumption of decreasing marginal utility of wealth such resistance would be greater the higher the amount of resources available to be redistributed. Efficient instruments that minimize the social losses associated with income redistribution will increase the amount of resources that can be obtained for any unit of pressure. Education and informational status affect the ability: (i) to identify efficient redistributive instruments; (ii) to evaluate the effect of any given instrument on own wealth; and (iii) to spread systematic misinformation about the impact of any given instrument. All three elements would bias redistribution in favor of individuals with higher education, putting peasants at a disadvantage. Furthermore, with non-zero cost of information acquisition-and the ability of interest groups to use obfuscating instruments of redistribution or even spread misinformation that fits preconceived ideological notions-it may be rational for the average rural voter to remain uninformed (Brock et al 1989) and therefore not to resist redistribution that puts him or her at a personal disadvantage.

Third, "investment" in political pressure or rent-seeking activities is extremely risky and yields results only with a long lag. Individuals would engage in rentseeking only if other investment opportunities with similar expected return are unavailable. The expected return from rent-seeking increases with the ability to obtain insurance either through markets for insurance, credit, access to noncovariate income, or via self-insurance provided by own wealth. High covariance of agricultural income risks (Binswanger and Rosenzweig 1986) makes insurance particularly difficult for the rural poor. If these risks are unmitigated, they will severely limit the ability of small peasants to devote resources to the production of political influence. 
Bates (1983) uses collective action variables to explain African agricultural policies. In addition to the superior collective action potential of large farmers, he also takes into account their ability to form coalitions with strategically important sections of the population. Alliances between industrialists, urban consumers and large farmers can explain policy regimes that tax a broad range of agricultural products, favor industry and attempt to compensate for such biases against agriculture through selective subsidies on agricultural inputs that benefit large farms.

Historically, the fact that poor rural people have borne the brunt of taxation suggests that a view of policy determination as a bargaining process among different interest groups may be appropriate. The main effect of different political decision-making mechanisms is to alter both the costs of political articulation and of changing governments.

The growing literature on the political economy of rent-seeking (Krueger 1974, Posner 1975, Tullock 1984) provides some insights into the interactions that take place between the various interested groups that result in governments implementing policies that discriminate against rural areas.

Becker (1983 and 1985) specifies a general model in which the representative member of a group maximizes his or her utility by spending resources on political activity (lobbying) to produce, according to a given production function, political pressure that will make politicians assess taxes and/or subsidies to produce private and public goods in a way that is favorable to him.

Under the assumptions that interest groups and their "pressure production function" are exogenously given, that information is perfect, that politicians act as impartial arbitrators, and that voting is costless, differences in the pressure production function drive the political economy model and become important in explaining actual policy outcomes. Of particular interest is the result that, if power is equally distributed, i.e., all groups have access to the same technology of pressure production, the compensation principle will hold and gainers could compensate 
losers. Investment would be made only in socially beneficial (public) goods. Even if there are differences in the power distribution, it can be shown that for any distribution of power, the most "efficient" method of redistribution will be chosen, because deadweight losses increase more than proportionately to the amount transferred. Given the observed redistribution of resources away from the rural poor, Becker's theory suggests that rural people have a very low capacity to articulate their demands in the political arena.

A number of applications of the conflict between different interest groups have been applied to agriculture. Hayami and Anderson (1986) have developed a theory of supply and demand for agricultural protection, which integrates elements from the theories of public choice and collective action, that explains the widespread practice in developed countries of subsidizing small agricultural sectors at the expense of consumers. They argue that at low levels of development neither supply nor demand for agricultural protection is high. Therefore, the agricultural sector is taxed in order to subsidize urban workers and industrialists via low food prices. At higher levels of development, the demand and supply curves for agricultural protection shift to the right. Consumers no longer spend a large part of their budget on food and, given that returns to farming do not rise fast enough to facilitate farmers' participation in general growth, agriculturists-who now face lower costs of organization-lobby for protection. This provides one possible explanation of why urban bias in developing countries transforms into rural bias in developed countries. The study does not, however, explain the distribution of gains and losses within the agricultural sector. It also appears to be at odds with some of the historical evidence, and with the fact that agricultural protection does not appear to be linked to relatively low growth in agricultural productivity.

Gardner (1987) provides an empirical illustration of the importance of the factors facilitating collective action. His econometric analysis of US data for 17 commodities from 1910 to the present, provides quantitative support for the predictions of the collective action model outlined above. 


\section{STRATEGIES FOR RURAL DEVELOPMENT}

In the post-war period, concern over the high level of rural poverty led donor agencies to develop specific interventions aimed at rural areas. Ruttan (1984) gives a history of these initiatives, the most recent of which was the integrated rural development (IRD) model. Through its Area Development Projects, the World Bank (WB) attempted to target the rural poor by providing a detailed, multi-sectoral package for RD. However, poor project performance and the failure to bring about a sustained improvement in the living standards of rural people led to a significant reduction in the number of ADPs and the abandonment of the "blueprint" approach to RD.

With the failure of IRD, the WB has been left without a specific policy aimed at poor rural areas. Yet the need for one has never been greater. The failure of donor agencies to confront the central challenge of RD-namely to tackle the complexity associated with providing a range of local goods and services that local people demand-is likely to render RD initiatives ineffective. Greater decentralization of power and authority to lower-level governments and communities may provide one mechanism through which the complexity issue may be addressed.

\section{Integrated Rural Development}

A policy paper prepared by the WB (World Bank 1974) defined RD as: “...a growth strategy for a particular target population-the rural poor. It involves extending the benefits of development to those whose futures lie in the pursuit of a livelihood in rural areas". The RD strategy developed by the WB during the 1970s was based on an integrated approach aimed at tackling rural poverty ${ }^{6}$. IRD programs typically contained similar components and emphasized increased agricultural productivity as the basis for raising rural incomes, while recognizing the synergistic contribution of better education, health and other basic services to further improvements in people's quality of life and their overall productivity. Project initiatives tried to achieve synergism between the various elements by using an integrated or "central planning" approach to local development. 
The WB's vehicle for implementing IRD was through Area Development Projects. The particular advantage of these schemes was perceived to be the opportunity to focus directly on the needs of the rural poor through diversified crop and integrated farming systems linked to training, social services and rural infrastructure projects. Projects were sometimes based on single agricultural products accompanied by other services that received a much smaller proportion of project funds, e.g., tea in Kenya, cotton in Mali or coffee in Papua New Guinea, but usually included broader approaches that had a more balanced lending across the sectors, e.g., the series of RD programs in northeastern Brazil, the PIDER projects in Mexico, the Lilongwe Land Development Program in Malawi, and three WBfinanced RD projects in Sri Lanka.

Difficulties with project implementation emerged early on. Government line agencies were perceived as inefficient, technically incompetent, understaffed and philosophically conservative. Dissatisfaction with their performance as program implementing agencies led administrators to advocate the creation of new, autonomous implementation units designed to by-pass the line agencies. However, experience suggests that "[a]lmost nowhere have these new administrative units been able to survive in the local political and bureaucratic establishment" (Lacroix 1985: 20), and they function only as long as they have the financial and administrative backing of an external aid agency.

Financial arrangements for implementing RD were also problematic and characterized by excessive delays in the release of funds and lack of counter-part funding from local agencies, both of which severely retarded project implementation. In the POLONORDESTE RD projects in northeastern Brazil, for example, project funding relied on annual central government budgets. The result was that funding varied significantly from year to year and the method of releasing funds was complicated and protracted.

Sub-projects for $\mathrm{RD}$ are usually small, often quite simple, and always widely dispersed. Central planning for hundreds of differentiated projects and localities is likely to fail because of the location-specificity of conditions and needs. Although RD 
projects did often complete a significant amount of infrastructure, they did poorly on other components because systems were not able to handle the complexity of multiagency, multi-project coordination associated with a centrally planned and executed effort. As WB project evaluation reports amply document, the desired synergism was not achieved, and by the mid-1980s disappointment with RD performance led to the development of a coherent critique of the IRD approach.

\section{Failure of Integrated Rural Development}

Apart from the operational difficulties associated with institutional and financial design, a more serious critique of the IRD model began to emerge in the mid-1970s. The limited focus of RD projects on increasing agricultural productivity; the insufficient attention paid to the wider context of national macroeconomic policy; the failure to develop technological packages that were sufficiently flexible to deal with local conditions; the lack of attention to sociocultural and institutional factors; and the scarcity of trained local manpower were all cited by Lele (1979) as major issues constraining the effectiveness of $\mathrm{RD}$ programs.

Ruttan (1975) identifies the difficulty of scaling-up from successful RD pilot projects to the regional or national level as the result of not being able to maintain the intensity of human resources devoted to organization, management and technical assistance. "Furthermore, access to the higher decision-making levels of government and the administrative freedom to tailor programs precisely to local conditions are frequently sacrificed to administrative convenience when projects are generalized. Highly centralized administration of national programs makes it difficult to carry out the experiments with program content and delivery methods that are essential if rural development programs are to meet the diverse needs of rural areas" (Ruttan 1975: 15).

Increasing concern with RD performance led WB to undertake its own review (World Bank 1987). Based on an in-depth analysis of completed project reports, a range of problems were identified: 
- Adverse policy environment: It quickly became apparent that IRD projects, when pursued in an adverse policy environment for agriculture were unlikely to succeed. Reform of the policy environment was seen as a prior condition for success. The greater success rate of IRD projects in Asia compared to Latin America and Africa supports this diagnosis.

- Lack of government commitment: Often governments did not provide the counterpart funding required for implementation of the programs, to the entire programs or to vital components thereof, despite assurances given in negotiations.

- Lack of appropriate technology: This proved important in unirrigated areas, especially of Africa, where there was no history of past commitment to agricultural research, or where colonial research efforts had decayed. An early remedy was to include project-specific research components, most of which failed and, in addition, undermined the national agricultural research systems by robbing them of talented researchers.

- Neglect of institutional development: By setting up project coordination units, sometimes staffed by expatriates, and using central or regional government line agencies, the development of local and district level institutional capacity to plan, execute and monitor rural development was neglected, and sometimes seriously undermined.

- Lack of beneficiary participation: The programs were often designed in a top-down approach within which beneficiaries were not given any authority for decision-making or program execution. Even if they were consulted in advance. they could not be sure that their preferences were being given adequate weight. Most often they therefore chose the only decision making option they had, voting with their feet.

- The complexity or coordination problem: It is ironic that complexity should have become the Achilles heel of RD. After all, building rural roads, small scale infrastructure or providing agricultural extension must be 
dramatically simpler tasks than the construction of largescale irrigation infrastructure or ports, where donors did not encounter a coordination problem. The coordination problem emerged as a consequence of delegating subprogram execution to government bureaucracies or parastatals that were typically highly centralized and had their own objectives. Many of them were out of touch with beneficiaries, who could have coordinated relatively simple tasks at the local level much more easily. At the community level, project implementation is often quite straightforward and information is readily available to local decision-makers.

While the critiques of IRD offer valuable insights and suggestions for change, they suffer from a problem of over-generalization and a tendency to concentrate only on aspects of programs that did not work. In reality, each $\mathrm{RD}$ project was a complex of successes and failures, as is demonstrated in Judith Tendler's detailed analytical review of the northeastern RD projects in Brazil (World Bank 1993).

Tendler highlights features of the RD process that worked in Brazil, often in spite of rather than because of the design of the official RD program. In particular, she demonstrates the central role played by fiscal issues in implementing $\mathrm{RD}$ programs. Against a backdrop of severe fiscal austerity at the time the projects were being implemented in Brazil, additional resources were mobilized by a variety of agencies above and beyond those expected at appraisal. "A considerable part of these additional resources came through municipal governments. Yet they had no formal role in the Northeast projects because they are typically seen as bankrupt, clientalistic, and technically inadequate,...The way in which the municipalities were drawn into resource mobilization, moreover, transformed them into a source of healthy outside pressure on state agencies to behave accountably, get things carried out on time, keep costs down, and use less sophisticated and capital intensive standards. Bank staff had tried, often to no avail, to accomplish the same thing." (World Bank 1993: xxii). 


\section{New Opportunities for Rural Development}

The failure of IRD left experts interested in rural poverty reduction in disarray. The WB has retreated from the ambitious agenda of the $1970 \mathrm{~s}$ into the support of more traditional sector-specific programs or projects, each dealing with a specific component of $\mathrm{RD}$, such as agricultural extension, smallscale irrigation, rural roads, primary education or health care, etc. This means that support for rural poverty reduction has become highly selective within the WB's program as nowhere has it been possible to support the full array of interventions that are required for successful rural poverty reduction.

The worst consequence of the failure has been the inability of donors to assist countries with advice on policies and programs that would enable them to implement successfully $R D$ programs and reduce rural poverty. Policy advice rightfully concentrates, inter alia, on eliminating direct and indirect distortions, supporting infrastructure and social investment in rural areas and for the poor, implementing land reform, reducing interventions via parastatals, strengthening agricultural research and extension. However, the question of how to implement the investment and support strategies that are recommended for rural areas is left unanswered. By withdrawing from an integrated approach to $R D$, donors have left the complexity and other implementation problems in the hands of the country governments. They have not disappeared just because the donor community has withdrawn from them.

Furthermore, the observations made in WB's $1974 \mathrm{RD}$ report concerning the justification for an integrated approach to RD remain: "Basically, arguments in its [area development] favor stem from consideration of the often complex nature of the target group situation, which calls for specific programs locally prepared and tailored to local conditions" (World Bank 1974: 27, italics added).

The fallacy of the policy response has been to assume that the complexity associated with $\mathrm{RD}$ is simply a planning issue that can be dealt with through having smaller, single-sector projects. Thus, the response to the criticisms of IRD projects has been partial, sidestepping rather than confronting the issue of complexity, and 
giving insufficient attention to structural problems that limit the effectiveness of desirable policy reforms. It has not been fully recognized that, at a local level, the coordination issues are often less complex and transparent than at a central level, and that local institutions may have the information, incentives and ability to achieve the desired synergism.

Ruttan (1984) is one of the few writers to have highlighted the lack of any sustained effort as part of RD projects to develop local government. He highlights the failure "to understand the difference between decentralized administration and decentralized governance-between locating the administrative offices of centre ministries at the provincial or district level and the strengthening of the fiscal and administrative capacity of local government" (Ruttan 1984: 395).

Facing the complexity issues associated with RD on their own, some developing countries have developed new policies and programs that attempt to build on the positive features of an integrated approach. These programs address the coordination problem through processes of decentralization that grant greater decision-making autonomy to local-level institutions.

\section{DECENTRALIZATION}

The interest in decentralization as a mechanism for transforming society is not new. Cohen et al cite nineteenth-century discussions between Lemennais, who characterized an over-centralized state as "apoplexy at the center and paralysis at the extremities", and Dupont-White, who argued that "the centralized state is the best instrument to destroy unfair and unproductive caste and privilege and smash the hold of local elites in the countryside" (1981: 3).

In the second-half of the twentieth century, practically every country has experimented with some form of decentralization or local government reform with varying aims and outcomes (Cheema and Rondinelli 1983 review decentralization initiatives of the 1970s; Campbell et al review recent Latin American experience). The present level of interest in decentralization is pervasive, and Dillinger notes that "out of 75 developing and transitional countries with populations greater than 
5 million, all but 12 claim to be embarked on some for of transfer of political power to local units of government" (1994: 8).

There have, however, been a number of recent developments that distinguish the present wave of decentralization from earlier attempts. First, democratic institutions have been established and/or their role extended in many countries. In Latin America, in particular, military regimes have been replaced by elected civilian governments, and local government officials-mayors and council memberspreviously appointed are now elected.

Second, most of the countries presently involved in decentralization initiatives recognize the importance of providing financial resources to decentralized institutions to permit them to carry out their powers and responsibilities. Lack of adequate funding for lower-level institutions was the single most important factor that undermined many of the decentralization attempts of the 1970s (Cheema and Rondinelli 1983).

Third, there is a growing realization that many types of institutions can actively participate in decentralization efforts. There has been widespread privatization of services that can be delivered on a commercial basis. In addition, it has been recognized that NGOs and community-level organizations have a significant role to play in improving service delivery and for providing improved mechanisms for targeting disadvantaged groups.

These developments are likely to enlarge considerably the scope for overcoming some of the major factors that undermined earlier decentralization efforts, and to improve the prospects for sustaining decentralization initiatives once they have been established.

\section{Defining Decentralization}

The terminology most often used to discuss decentralization is that proposed by Rondinelli (1981), who distinguishes between four different categories of decentralization: (i) deconcentration is defined as a transfer of power to local 
administrative offices of the central government; (ii) delegation is the transfer of power to subnational governments and/or parastatals, or other government entities; (iii) devolution is the transfer of power to subnational political entities; and (iv) privatization is the transfer of power to the private sector.

Deconcentration. The "training and visit" (T\&V) system of agricultural extension provides a good example of deconcentration of responsibility. Developed during the $1960 \mathrm{~s}$, the T\&V system aimed to address criticisms of existing extension arrangements. In India, the $\mathrm{T} \& \mathrm{~V}$ system was introduced state by state, replacing the system of multipurpose village-level workers. Under the T\&V system, staff deal only with extension work. They are organized into a unified extension service with a single line of command, but still under the state-level Ministry of Agriculture. Extension work tasks are precisely defined and systematic visits to target farmers are undertaken.

Feder and Slade (1986) estimated a rate of return of 15 percent on the incremental investments in $\mathrm{T} \& \mathrm{~V}$ in India, indicating overall success as far as productive resources are concerned. Other studies, outlined in Hulme (1992), give more mixed results. Questions have been raised concerning the ability of the system to reflect adequately and respond to the needs of farmers. Poor research-extension linkages ${ }^{7}$ and a lack of performance-related incentives for extension workers have also undermined the system.

These criticisms suggest that deconcentration is an incomplete strategy for decentralization. Although the $\mathrm{T} \& \mathrm{~V}$ system appears to provide improved mechanisms for transferring information to farmers, the farmers themselves do not possess overall decision-making power. Thus, although deconcentrating power to local administrative offices has improved the governmental organization of extension services, the impact of the $T \& V$ system in terms of being more responsive : 'to farmers' needs has been more limited.

Delegation. Between 1975 and 1987, the Brazilian government implemented 22 IRD projects in the ten states of Northeast Brazil. Both the Federal and State 
governments had responsibility for project organization for the two generations of projects: POLONORDESTE (Program of Integrated Development for the Northeast) and PAPP (Program of Assistance to the Small Farmer). To provide a focus on the northeastern projects and to enable some decentralization of decision-making the government established SUDENE (the Northeast Regional Development Agency) as a parastatal with overall responsibility for annual project planning, budgeting and M\&E. Actual project implementation, however, was the responsibility of the States. There was a complex approval system for funding transfers and authorizing changes in project design that required the approval of SUDENE, WB and sometimes the relevant ministry at the federal level.

Not being well-integrated into the pre-existing institutional structures in Brazil, SUDENE became at least irrelevant and more often a hindrance to project implementation. Although it was an institution designed to focus on a single important element of the government's development strategy, the hoped for benefits of decentralizing project administration to a parastatal were not realized. The recent reformulation of the northeast $R D$ programs undertaken by WB has recognized the inappropriate role of SUDENE in program implementation and has turned over most of its program responsibilities to the States. As with deconcentration, delegation appears also not to be sufficient on its own to guarantee improved RD outcomes.

Devolution. In the post-independence constitution in India, states were given strong powers to administer their own development programs. The constitution also required elections at the village and district levels for local governments-the Panchayati Raj. However, decisions concerning the assignment of functions and resource transfers to these local governments remained at the state level. Most states starved these local governments of resources and let the electoral process at the village and district level break down.

In the 1980s, state governments in West Bengal and Karnataka revived the Panchayati Raj system and mandated district elections to councils at village, block and district levels. To make this political decision meaningful in practice, elected 
councils were given substantial authority and resource allocations to decide their own development spending. Although opposed initially by the state bureaucracies, devolution has produced a system which was patently more responsive to the felt needs of people at the village level.

Devolution may include elements of both deconcentration and delegation, but it goes beyond these decentralization strategies by recognizing the important role that political and fiscal control plays in better satisfying the demands of the beneficiaries of RD.

Privatization. In response to criticisms of poor service delivery from publiclyowned institutions, and to fiscal crises in many developing countries, governments have embarked on programs of privatizing services associated with RD. A series of papers Umali (1992), Umali et al (1992), Jaffee and Srivastava (1992) and Umali and Schwartz (1994) have investigated the appropriate role of the private and public sectors for agricultural research, livestock services, seed production and distribution and agricultural extension respectively.

With regard to agricultural extension, for example, there are now numerous instances where the private sector has become involved in service provision that was previously managed by the public sector. These include agro-processing firms, input suppliers, farmers associations, media companies and consulting firms. Farmer associations for vegetables in Turkey and Uganda, poultry in Thailand, tobacco and cotton in Zimbabwe, dairy products in India have all become involved in providing extension and other services to farmers. These institutions are likely to reflect better the wishes of beneficiary farmers else they will not be able to survive commercially. However, there are concerns about the selective participation of the private sector, especially as it is likely to operate only in areas where the economic returns to delivery are sufficient. This will necessitate a continued role for the public sector in providing agricultural services.

The Rondinelli terminology is useful for describing processes of decentralization and for distinguishing differing types of sectoral arrangements where, given the 
different nature of goods and services provided, different combinations of deconcentration, delegation, devolution and privatization will be required.

Besides the Rondinelli terminology, a further analytical refinement can be discerned in the literature between the political, fiscal and institutional dimensions of decentralization. The examples cited above of different types of decentralization indicate how easy it is to undermine one type of decentralization by not giving sufficient attention to other elements of decentralization. For example, the Panchayati Raj experiments in India failed to decentralize fiscal resources to local institutions, effectively rendering useless the attempt to devolve political power on its own. In Brazil, failure to consider existing institutional arrangement left SUDENE isolated and irrelevant to the decentralization process.

In most of the literature to date, however, emphasis given to these broader political, fiscal and institutional elements of decentralization has been segmented according to different disciplines. Thus, political scientists have stressed the political components of decentralization and underplayed the other dimensions; the public choice literature has focused on fiscal issues; and the institutional dimensions of decentralization have often been given insufficient attention, due to the difficulty associated with characterizing the role that NGOs and other community-based organizations might play in decentralization. The result is that no framework has been identified that assesses all the dimensions of decentralization and their interlinkages.

\section{Political Decentralization}

As the political dimensions of decentralization are generally concerned with increasing public participation through citizens' active engagement in public institutions, all programs of decentralization require formal government commitment to initiate the process. As Arthur Lewis observed almost thirty years ago, "[t]he chief obstacle to further decentralization is political" (1967). If the overriding political environment is not conducive to reform, decentralization is unlikely to be on a government's agenda. As Harris notes in his review of decentralization in Latin America in the 1970s, "[b]ecause of the dominant 
centralizing tendency and premature bureaucratization of the Latin American political systems, the prospects in general are not very favorable for the successful implementation of forms of political and administrative decentralization that are based on the devolution of power from the national to the local level" (1983: 198).

The imfortance of the overall political environment can be seen in subsequent decentralization initiatives that have been introduced in many Latin American countries following the transition from autocratic to democratic forms of government that took place during the $1980 \mathrm{~s}$. Political transition provided a window of opportunity to introduce important constitutional reforms that permitted the introduction of more decentralized systems of government in Argentina (World Bank 1990), Chile (World Bank 1992b), Colombia (World Bank 1989), and Venezuela (World Bank 1992a).

Crook and Manor's (1994, hereafter C\&M) comparative analysis of decentralization in South Asia and West Africa is one of the most thorough recent reviews of decentralization. Governments in Bangladesh, Cote d'Ivoire, Ghana and the Indian state of Karnataka all committed themselves to introducing systems of democratic decentralization. It was hoped that by bringing decision-making closer to communities and encouraging their direct involvement in the political process, the prospects for sustained RD would be significantly enhanced. Political decentralization was therefore associated with the devolution of specified powers and responsibilities from central government to lower-level political entities. However, the motivation and aims of central governments in devolving political power can vary widely. In the Indian state of Karnataka, a state government in opposition to the national government wanted to demonstrate that it was more imaginative and democratic than its rival to promote its fortunes nationally, and hoped to develop grassroots support by putting in place a system of locally elected councils (C\&M).

Ironically, giving life to local political institutions may increase the opportunity for collusion between locally-based elites and the center. This is the political legitimization of the "urban alliance" Lipton refers to in his description of urban 
bias, and will likely lead to a worse outcome for rural populations. In Bangladesh, for example, the Ershad regime hoped to gain control of decentralized, elected councils by making sub-district council Chairmen dependent on patronage from the center (C\&M).

Understanding the underlying intent of central government is therefore an important first step in analyzing decentralization initiatives. In turn, this intent will be conditioned by the historical economic, social and political antecedents of a particular country. Thus, in the case of Côte d'Ivoire, the centralizing tendency of the French colonial administrative system combined with traditional social structures that recognized the work of local elites according to their efforts to help their own home towns led to a decentralized system characterized by greater rather than lesser dependency on the center (C\&M).

If we adopt the view that political decentralization is associated with the devolution of power to subnational political entities, it is clear that many of decentralization initiatives of the 1970 s that were termed political, particularly those in north and east Africa reviewed by Nellis (1983) and Rondinelli (1983) respectively, were far more administrative in nature and did not involve devolution of powers and responsibilities. For example, in Kenya administrative structures were established with centrally-appointed administrators, using old and mistrusted colonial names, who owed their position to the center. The results was a lack of locally perceived legitimacy to these arrangements, a major reason for their failure.

In contrast to decentralization initiatives in the $1970 \mathrm{~s}$, recent efforts have focused on encouraging greater public participation through the institutions of representative democracy, as the importance of popular participation has received greater recognition and as concern with improving democratic processes has increased. Although democracy is not a necessary part of decentralization, its presence can have a significant influence on the perceived legitimacy of decentralized systems. Democracy does appear to improve methods of accountability, although an important proviso to this statement is the impact on disadvantaged social groups. In their research, although C\&M found that poor 
people or women did participate more under decentralized systems, they found no evidence that either poverty or gender issues received a higher priority in the development process.

Even in repressive political environments, democratic electoral processes do offer the opportunity for local communities to reject incumbents. In Bangladesh, even though many local council leaders were able to dominate local decision-making and use the opportunity for self-aggrandizement, more than 90 percent of them were not reelected ${ }^{8}$. In more open systems, the impact of democracy on accountability is likely to have a beneficial impact in motivating local politicians to meet the felt needs of local communities. Satisfying communities' perceived needs is a central requirement to maintain legitimacy of authority. Thus, in Karnataka, decentralization caused resources to be directed away from government services and toward the construction of micro-level physical works, such as roads, bridges and buildings. This reallocation is in part a reflection of the strong local demand for such types of projects, support for which was not realized under a more centralized political system (C\&M).

Meeting local demands as mediated through democratic processes may strengthen the autonomy of devolved local institutions. This may bring them into conflict with national governments, as local authority also derives from the center, which retains the ultimate sanction of taking back devolved powers. In India, the post-independence constitution encouraged the establishment of local, selfgoverning bodies from the village to the district (the Panchayati Raj) and permitted states to support this process by allowing for local elections to these bodies. However, the constitutional provisions did not require local bodies to be established or elections held. As political decentralization would often have challenged the entrenched bureaucratic practices of state governments' administrative departments, only a few states experimented seriously with the ideas. The state governments of Maharashtra and Gujurat did, however, implement Panchayati Raj programs in the late $1960 \mathrm{~s}$, only to find the experiment in decentralization becoming too successful and, feeling threatened by the emergence of new local centers of power, terminated the program (Webster 1990). 
Another key issue with respect to implementing decentralization is the relationship between the political and bureaucratic institutions of decentralization. Most decentralization initiatives stipulate a range of rules and regulations covering the interaction between local councils and central government line agencies. How these rules are interpreted in practice will have a decisive impact on the successful implementation of a sustainable system of decentralization that delivers more of the goods and services local people demand.

In Karnataka, decentralization brought more elected representatives into the process of RD. The quantity and quality of work undertaken by line agencies was closely monitored and problems reported early, and it became harder for bureaucrats to get away with corrupt acts. The result was enhanced institutional effectiveness and improved coordination among civil servants working for different line agencies (C\&M). In Ghana, despite the law on local government giving an active role to elected councilors, their ability to take control of the bureaucratic administration was, in practice, limited by the District Secretary, a central government appointee over whom the council executive did not have clear authority (C\&M).

Decentralization initiatives that focus exclusively on electoral and administrative processes without considering the fiscal and institutional dimensions will not be sustainable. In Nigeria, a rapid increase in the number of local governments from 301 in 1979 to over 700 by 1982 led to an inevitable reduction in the finances and technical personnel available to any one local government. In addition, although local governments were to receive 10 percent of the federation account and 10 percent of state revenues, state governments proved able to divert these funds for their own use (Meenakshisundaram 1994).

It is important to understand the political limitations of decentralization. Central governments will promote and support processes of decentralization so long as they contribute to whatever political goals the center hopes to realize. Where decentralization brings undesirable change, e.g., when local interests challenge national ones, decentralization can be swiftly reversed. 


\section{Fiscal Decentralization}

If decentralized institutions are to perform the responsibilities devolved to them, they will need an appropriate level of fiscal resources to cover the costs of providing rural public goods and services. Three main sources of revenue are available: own. locally-generated resources; transfers from higher-level institutions; and resources from borrowing 9 .

Own Resources. As we have seen in the earlier discussion on rural areas, the level of revenues that can be mobilized locally is severely restricted. General skepticism about the financial management capabilities of local institutions, coupled with a reluctance on the part of national governments to give up control of resources has resulted in local authorities' ability to tax typically being curtailed or denied entirely. For example, in Zambia, where a recent initiative aimed to put in place a matching grant program for $\mathrm{RD}$, it was discovered that District authorities had no power to raise revenues and so had no resources to match with central government funds.

Even where local communities do have the power to raise local revenues bestowed on them, this will not necessarily result in them taking advantage of this option, especially if central government prescribes tax rates and defines the tax base. The administrative costs associated with collecting local taxes may be prohibitive. In Indonesia, subnational governments have access to more than 50 taxes, but more that 80 percent of revenues collected come from only two taxes (Shah and Qureshi).

In addition, improperly designed programs of subnational revenue-sharing may provide perverse incentives to local institutions not to maximize local fiscal effort. In Brazil, due to the generous provisions of revenue-sharing arrangements implemented in 1990, some municipalities increased public sector payrolls and wages, and lowered local property taxes.

There is clearly the potential for macroeconomic imbalance if local governments are permitted too much revenue-raising autonomy. If local governments are allowed 
unrestricted borrowing without an appropriate system of checks and balances, fiscal problems can rapidly emerge. A fine balance must be found between designing a system of accountability that prevents severe fiscal imbalance, but at the same time does not place unnecessary restrictions on important local fiscal decision-making. For example, restricting local authorities' ability to tax at rates they set breaks an important avenue for increasing accountability, as local political processes offer the possibility for rejecting high-tax incumbents.

Writers often assert that local communities do not possess the resource base to mobilize enough resources (Therkildsen 1994). While it is true that poor, rural areas are unlikely to be able to cover all their expenditures, it is also the case that they are rarely permitted to raise any at all. Given the opportunity to manage their own financial affairs, local governments have demonstrated an ability to raise revenues and provide a wide range of services (Smoke 1992).

Intergovernmental Fiscal Transfers. Although greater flexibility in permitting local institutions to mobilize their own resources may result in increased funds at the local level, rural areas are likely to continue to be highly dependent on transfers from higher-level governments. The appropriate design of intergovernmental fiscal transfers (IGFT) is therefore of great importance, and there is a rapidly developing literature ${ }^{10}$ that seeks to define a set of principles to guide governments in their design of IGFT.

To meet efficiency and equity goals, four main economic arguments have been suggested as justification for IGFT:

- to bridge the fiscal gap that may result from a mismatch between revenue means and expenditure needs, leading to a revenue shortfall;

- to compensate for the presence of interregional differentials in income and resource capabilities that creates inefficiencies due to fiscally-induced migration, as factors of production gravitate toward richer areas; 
- to ensure common minimum standards across jurisdictions to enable poorer areas to provide an acceptable level of service; and

- to alleviate inefficiencies arising from interjurisdictional spillovers, where people enjoy the benefits of a public good but do not contribute to the cost of providing it, possibly resulting in subnational levels of government considering only the benefits that accrue within their own jurisdiction and under-providing the public good.

Based on these arguments, the theoretical and practical literature on decentralization has developed some useful advice on designing IGFT. Few countries have, however, implemented grant programs that incorporate efficiency and equity goals, and possess the desirable qualities of: (i) transparency-the basis on which transfers are made, sometimes through an equalization formula, must be clearly stated; (ii) predictability-IGFT mechanisms should ensure predictability of subnational government shares from year to year to permit strategic planning; (iii) and autonomy-subnational governments should have complete independence and flexibility in setting their own development priorities.

Grant Design. In many developing countries non-specific, general grants continue to be the most important type of IGFT. They are often made on an ad hoc basis, entirely at the discretion of central governments, with little effort to develop objective grant design criteria. A few attempts have been made, however, to include specific formulae designed to address issues of horizontal and vertical fiscal imbalances, e.g., the Brazil Municipal Participation Fund, which considers municipal population and state per capita income in the determination of fiscal shares for individual municipalities. The design of this grant program is an improvement over purely ad hoc arrangements, although problems still remain with the revenue-sharing formula (Shah 1994).

Of greater relevance for the specific financing of $\mathrm{RD}$, are conditional grants, both matching and non-matching. Imposing conditions on grant use provides central governments with the opportunity to target resources to support specific initiatives 
and/or provide funds for goods and services that may be under-provided at the local level, e.g., poverty programs, and environment and conservation projects.

Non-matching grants transfer lump-sums from central governments to subnational governments for specific purposes. Indonesia has a major program of block grants-Inpres-that cover many sectors, e.g., primary education, health, transportation, and reforestation and conservation. The latter, Inpres Penghijaun/Reboisasi, is designed to encourage reforestation, soil conservation and regreening activities in environmentally critical areas. Grant allocation is made on a project-by-project basis and approved projects take three components into consideration: (i) the land area to be regreened, (ii) the area to be conserved, and (iii) field staff requirements. Other transfers are made on the basis of various formulae designed to take into consideration critical indicators of need (Shah and Qureshi 1994).

This type of non-matching grants does not, however, require local governments to contribute any of their own funds. There is, therefore, no incentive for local communities to mobilize resources to fund expenditures covered under the grants. Matching grants, on the other hand, require subnational governments to contribute funds of their own if they are to obtain access to counterpart funding from central government. They involve a significantly enhanced role for local governments in decision-making about which projects and programs to support at the local level.

In Brazil, there are a large number of federal and state specific-grant programs, but most have insufficiently defined program objectives. A few grant programs are well designed, including the unified and decentralized health system-SUDS (Sistema Unificado e Decentralizado de Saude)-where federal financing is provided to achieve certain minimum standards of health care across the nation (Shah 1994). In India, specific-purpose-plan grants attempt to provide higher assistance to relatively less well-off states in addition to encouraging tax effort at subnational levels; however, drawn out review and approval processes may work against these goals (Shah 1994). 
The problem remains that even for these types of specific grants objective allocation criteria are often absent or inappropriate, leading to ad hoc grant distribution that is at considerable variance with the principles of transparency, predictability and autonomy. There is therefore considerable scope for improving the effectiveness of these grants.

Winkler (1994), reviewing grant design and administration for education and health in Chile and rural roads in Colombia, found that modifications to grant design have the potential for realizing considerable economic benefits. The results of his simulations provide some important conclusions: (i) a simple grant design may attain central government objectives as well as a complex design; (ii) price incentives, especially through matching grants, can work just as well as expenditure mandates in increasing available resources; and (iii) central governments can best leverage the effect of their transfers on total expenditures by including some measure of the local jurisdiction's fiscal capacity, although this can increase the complexity of grant design.

The earlier political economy discussion of how urban-based, industrial interests are able to dominate poor rural communities suggests why central governments have not been interested in designing resource-transfer programs that benefit rural areas. It is not surprising therefore that Shah (1994) finds no single country that has designed a system of IGFT that contains all the desirable elements of transparency, predictability and autonomy. There is an inherent tension between a central government that on the one hand recognizes the potential gains possible from decentralization, while on the other is reluctant to give up real power with uncertain political outcomes.

\section{Institutional Decentralization}

From the perspective of central governments, the institutional dimensions of decentralization are concerned with defining which formal, government institutions are to be involved in a decentralization program, and the development of an appropriate legal framework that defines the relationships between different institutions. From the perspective of rural people, however, the institutional 
situation they confront is likely to be far more complex and varied. It is not surprising, therefore, that generalizations in the area of institutional decentralization are particularly difficult to define. Nevertheless, there do appear to be a set of discernible conditions that enhance the prospects for successful decentralization.

First, there needs to be a clearly established legal framework that defines the decentralized institutions, how they are to be constituted, and how they relate to other institutions. If pre-existing institutional arrangements can be appropriately modified, this task is likely to be more straightforward than in the case where a new set of institutions is being created. Thus, in Karnataka, the state government was able to draw on long-standing enabling legislation that clearly defined institutional arrangements for decentralization. Government line agencies had already been deconcentrated prior to the implementation of political decentralization. By contrast, in Ghana, where the Rawlings government attempted to put in place a new system of deconcentrated line agencies, four years after the legislation was passed these arrangements had not been finalized (C\&M).

Second, an active civil society appears to assist significantly in implementing decentralization. Putnam's (1993) concept of "social capital" is useful in focusing on the level of associational life in different societies, and highlighting the range of institutions available to participate in decentralization programs. In Ghana, for example, local communities have well-developed political, moral and legal institutions and possess identities that have been encouraged through political competition and participation, and the overlay of party, class and associational groupings. It is no surprise that the largest impact of decentralization in Ghana was felt in the political arena, and participation in the form of electoral turnout was high. In contrast, the results of decades of one-party rule in Côte d'Ivoire resulted in "the almost unnatural quiescence and political apathy of the Ivorian countryside noted by many observers, and the underdevelopment of small town life..." (C\&M: 105) 
In Bangladesh, the process of decentralization did permit more opportunities for NGOs to lobby on behalf of disadvantaged groups, and some groups of the poor and women were able to achieve limited inputs into the decentralized system. However, the repressive nature of rural social relations resulted in local elites being able to exert a significant degree of dominance and prevent more substantial participation (C\&M).

The concept of social capital is not without its practical problems, most notably how can its components be defined and characterized? Furthermore, if, as asserted, social capital matters, we need suggestions as to how it can be built? These are questions beyond the scope of this article, but need to be addressed in future research.

Third, decentralized institutions need to have the capacity to carry out the powers and responsibilities devolved to them. In the context of $R D$, capacity means being able to do the job and actually improve service delivery. However, the concept of institutional capacity has also proved difficult to define objectively. For example, the existence of a large number of qualified personnel within a decentralized institution, or adequate project financing is only indicative of the presence of capacity, but does not guarantee it.

As we are primarily concerned with the delivery of goods and services, it is possible to adopt a specific interpretation of institutional capacity that focuses on: the degree of resource mobilization; cost-effectiveness in service provision; and performance with respect to meeting minimum standards of service provision. Based on this interpretation, lack of institutional capacity may be reflected in one or more of the following:

- inadequate funding to meet minimum standards of service and provision;

- inability to mobilize fully all resources available from tax bases, revenuesharing arrangements and/or matching grant programs;

- failure to deliver goods and services cost-effectively; and 
- an inappropriate mix of services in relation to local preferences.

Findings of a study on municipal local government capacity in Colombia (World Bank 1995) suggest that there is considerable latent capacity to be exploited at the local level, if municipalities are given an active development role. By using existing, but underutilized capacity and through locally-initiated efforts to upgrade capabilities most of the municipalities selected were able to meet effectively new challenges posed by decentralization.

The study found that capacity does not necessarily increase with jurisdictional size. Although small municipalities did have some difficulties obtaining appropriate professional support, they were successful at implementing a range of simple RD. related projects. Large municipalities, with populations over 80,000 , generally have significant resources to draw on and had sophisticated organizational structures that enabled complicated activities to be successfully implemented. Medium-sized municipalities (30,000-80,000 people) faced the largest challenge as the relative costs of improving capacity are high and must be spread over time. This requires a long-term commitment that may conflict with the political realities posed by a system that elects mayors for a single term of two years.

The Colombian experiment in decentralization seeks to give political power to decentralized local institutions, to provide them with resources to carry out prescribed functions, and to permit the inclusion of a wide range of institutions in the decentralization process. Focusing on the design of the political, fiscal and institutional elements of decentralization together has significantly increased the potential for successful RD outcomes.

Fourth, there needs to be a proper system of accountability for decentralized institutions to each of their different constituents, and some system of sanctions that penalizes institutions that fail to carry out their functions appropriately. Where accountability is absent, the legitimacy of a decentralization initiative can be lost quickly. In Ghana, where District Administrators were able to retain effective power because of their ties to the center, local scandals involving embezzlement of 
public funds went unpunished. In Bangladesh, again because sub-district council chairmen derived most of their power from the Ershad regime in Dhaka, they were permitted to do more or less as they wished and were able to make considerable private profits (C\&M).

Concern with the institutional dimensions of development is a relatively new phenomenon. This is clearly reflected in earlier decentralization initiatives in Africa and Asia that focused almost entirely on the administrative institutions of government. In Kenya, the District Focus for Rural Development was implemented almost entirely through deconcentrated line agencies of central government. The exclusive focus on government institutions enabled the central bureaucracy to retain effective power and served to alienate rural people rather than to bring them into the development process:

"Rural people refused to participate in family planning clinics in some areas of Kenya because they thought the programs were established to castrate men before drafting them into the armed forces. They did not allow land to be used for agricultural demonstrations in other places, fearing that government would later take over the improved property. Rural road construction was disrupted by some rural villagers who thought that the new roads would allow government patrols to catch stock raiders more easily." (Rondinelli 1983: 109)

Recent USAID experience in Peru suggests that capacity-building approaches to improving decentralized institutions need not only to include diffusion of the technical and organizational abilities but must be made with reference to the broader political system. As Schmidt observes "capacity-building efforts in highly centralized systems, such as Peru's, soon run into limits related to central constraints. At some point, political and administrative reforms at the center will be needed to allow continuation and expansion of such efforts" $(1989,109)$.

Although the decentralization experiments in the late 1980 s and early 1990 s did see the scope of institutions utilized broadened to include elected local councils with 
devolved powers and responsibilities, other types of institutions, e.g., nongovernmental organizations, were still perceived as peripheral.

More recent development programs have begun to encourage actively the involvement of community groups and NGOs by channeling resources for specific smallscale productive or social projects to beneficiary groups, either directly or via intermediation through NGOs. This Social Investment Fund approach (Grosh 1994) has flourished in many countries, often where bureaucratic or political institutions have been. Governments, bilateral donors and multilateral lenders have increasingly resorted to this method. Social funds delegate planning and execution to beneficiary groups or their NGO agents, but they leave ultimate approval and disbursement authority with central project units-the Social Fund administrators.

\section{DeCENTRALized RuRal DeVElopment}

Previous initiatives have often regarded decentralization as a desirable end in itself-contributing to greater participation and bringing decision-making closer to the people-rather than as a means of achieving improved RD outputs and outcomes. However, our concern is for decentralization as a means to achieve improved RD outputs and outcomes.

The outputs of RD are the tangible goods and services provided by the range of decentralized institutions involved. Ultimately, this will involve the task of assigning powers and responsibilities to the different institutions on a sectoral basis at the subfunction level. Some countries, especially in Latin America, have carefully worked through the assignment process and have implemented programs of decentralized $\mathrm{RD}$ that address the three dimensions of political, fiscal and institutional decentralization.

\section{Sectoral Decentralization}

The literature that has dealt with issues of sectoral decentralization has been primarily concerned with distinguishing between which level of government should have responsibility for which sector. Shah (1994), for example notes that while central governments' role in national defense and security and other issues of 
national concern are well recognized, the over-extension of their powers into purely local functions, such as pothole repair or pest control, is being questioned. His review of the theory and practice of revenue and expenditure assignment suggests that problems associated with governmental responsibility arise mainly out of de facto assignments being at variance with de jure responsibilities.

However, a further functional disaggregation is needed in most of the sectors relevant to $\mathrm{RD}$ in order to assign powers and responsibilities. Each sector will have a range of subfunctions associated with it, some similar across sectors, others differing due to the nature of the good being provided.

For example, rural roads are mostly a public good, when there is relatively little traffic, where the benefit one individual derives from using a road does not negatively affect the benefit another individual derives from using it. Everyone in a community is likely to have an interest in building and maintaining a road, so there is no conflict between the interests of local elites and the poor. Roads are easily observable, making transparency easier to achieve. The technologies required to construct rural roads are simple and local populations are likely to be able to provide the necessary skills.

Primary health care, on the other hand, is entirely different. It is mostly a private good. Local elites can exclude the poor and have little interest in the availability or equality of the publicly financed service. Use of the service is not easily monitored, so transparency is a problem. The technology is relatively complex and requires skilled manpower that is unlikely to be available locally.

Natural resource management issues are different again. In the case of national park management, local populations may have diametrically opposed interests to the national or international community. The costs and benefits of particular programs are difficult to measure and are often external to the immediate area, making decisions about appropriate levels of service hard to estimate.

Given the sector-specific nature of decentralization arrangements demonstrated by the striking contrasts across sectors, there is a need to undertake detailed 
investigations into how each sector should be organized and identify appropriate fiscal and institutional frameworks for delivering services effectively. Winkler (1988), for example, in assessing whether an educational system is centralized or decentralized argues for the need to look at the distribution of decision-making authority with respect to various educational factors. He proposes three questions that provide the basis for discriminating between centralized and decentralized systems of education:

"(i) Who selects the chief administrative officers of the local schools, and what control do they have over resource allocation?

(ii) Which level of government is responsible for recruiting and promoting teachers? Is there a national pay scale?

(iii) What proportion of total expenditures is financed through local revenue sources, both tax revenues and voluntary contributions?" (Winkler 1988: $11)$.

\section{Recent Experience from Latin America}

As yet there are few examples of IGFT specifically designed for RD in developing countries. However, early analysis of matching grant programs in Colombia, Mexico and Brazil suggests that the combination of political, fiscal and institutional decentralization can not only be effective in increasing the availability of resources for $\mathrm{RD}$, but also results in greater beneficiary participation and influence over the decision-making process, and ultimately to improved RD outcomes.

\section{Fondo de Desarollo Rural Integrado (Integrated Rural Development} Fund), Colombia. The Fondo DRI was developed to provide funds to municipalities to finance small investment sub-projects on a matching grant basis. Local communities provide labor and local material, and municipalities contribute a portion of the cash cost. Communities are involved from the outset through the identification of needs, the selection of sub-projects and the monitoring of subproject 
execution, as well as participating directly in execution and subsequently operation and maintenance of the completed sub-projects.

Selected sub-projects are presented for funding to the Fondo DRI, which carries out the appraisal of each subproject. Only sub-projects that meet predetermined criteria, including established technical and environmental standards and a requirement that beneficiaries be low income rural families, are approved. Subproject preparation is the responsibility of the municipalities themselves. Fondo DRI directly enters into contracts with municipalities to fund the sub-projects. In turn, municipalities enter into agreements with communities and private contractors for the execution of the works or services.

Eligible sub-projects cover a wide range of $\mathrm{RD}$ components, including: rural roads; water supply; rural electrification; watershed management; minor irrigation; agricultural extension; marketing; organization and training of communities and farmers' groups and projects targeted at women. Fondo DRI financed about 1600 individual projects in 1993 , amounting to $\$ 38$ million, partly funded by WB and the IDB.

A key element of the Fondo DRI's strategy is aimed at reaching poor municipalities that have some agricultural potential; however, these municipalities typically do not express their demand for sub-projects as effectively as richer municipalities. To redress this imbalance, Fondo DRI includes an important capacity-building component designed to strengthen weaker municipalities. It has also developed a mechanism-the cofinancing matrix-for targeting resources at poorer municipalities and at less privately profitable investments, with potentially large spillover effects, that are least attractive to municipalities. For example, funding natural resource conservation or agricultural extension projects in poor areas could attract a cofinancing share of up to 90 percent, whereas funding attractive infrastructure projects in richer municipalities would attract a nominal 10 percent rate of cofinancing. 
Municipal Fund Program, Mexico. The Municipal Solidarity Funds (FMS), implemented under the umbrella of Mexico's National Solidarity Program, are aimed at strengthening the capacity of local municipal government. Introduced in 1990, the FMS have been designed to demonstrate how a locally managed fund may be a successful alternative for managing rural investment in technically simple infrastructure. They are intended to overcome many of the problems associated with centrally planned and implemented rural infrastructure projects, as the selection, budgeting and execution of projects is carried out by local municipalities and their communities.

The program is now functioning in most of Mexico's 31 States and has financed about 75 thousand projects over the past four years. Mexico's four poorest States have benefited particularly through the Decentralization and Regional Development project, partly financed by WB, with 653 rural municipalities receiving $\$ 32.5$ million during 1992.

No complete analysis of the impact of the FMS on municipalities has been carried out to date. However, a preliminary report on the operation of the FMS in Oaxaca State draws the following conclusions:

- The FMS program is viewed positively by both municipal leaders and project participants. Although the funds distributed per municipality were very small and were not always used to finance the most pressing community needs, actually having a specific budget for local projects was perceived as a major step forward.

- The FMS has encouraged a shift in the intra-rural resource balance away from the municipal headquarters by directing resources to outlying areas. For many rural municipalities, the FMS program represents the first regular source of project funding, which has enabled benefits to be targeted at the poorest areas and has increased their political voice within local government.

- The program has not, however, brought about any change in the relationship between state and municipal governments. The state government did not 
encourage greater municipal autonomy, nor did it develop the institutional capacity of municipalities to manage their own affairs.

- The impact of the FMS program on local development has been constrained due to the low level of grant allocated to each municipality (approximately $\$ 17,000$ per municipality) and the lack of adequate technical assistance. Having insufficient funds to hire private sector advisors, municipalities have to rely on technical services provided by the State government with all the inherent problems associated with public sector agencies.

Fundo Municipal de Apoio Comunitario (FUMAC), Brazil. As part of a reformulation of ten RD programs, partly funded by WB, being implemented in the north-eastern states of Brazil, a community support program was initiated by which municipal councils would be established to screen and set priorities among proposals generated by poor rural communities before submission to state technical units. The FUMAC program is an extension of the Programa de Apoio Comunitario (PAC), which does not involve municipal councils and requires all project proposals to be approved by state technical units.

Results of a study (van Zyl 1995) suggest that FUMAC has outperformed PAC in a number of ways. FUMAC projects are more cost-effective per beneficiary. They reach more beneficiaries per comparable project; cost savings are realized in project design and implementation; and overall costs are 15-75 percent cheaper per beneficiary.

The more participatory approach encouraged by FUMAC appears to have achieved better targeting of poor people, mobilized additional resources by requiring direct community contributions, and attained greater sustainability through increased community participation.

The impact of these three programs in Latin America on developing the capacity of rural municipalities to respond to the needs of their communities is likely to be as important in the long-run as the immediate impact achieved through specific project 
investments. For the first time, rural municipalities are taking an active role in local development in partnership with their communities.

\section{CONCLUSIONS}

We have emphasized decentralization as a multi-dimensional process that proceeds with successes and setbacks. Decentralization initiatives will therefore be subject to a continuous process of modification reflecting changes in social, political and economic conditions. What emerges from the previous discussion is the need to include all three dimensions of political, fiscal and institutional decentralization. We have proposed a souffle theory of decentralization that recognizes the impossibility of designing a single strategy for decentralization, and instead illustrates the importance of different decentralization components and suggests factors that appear to have either a beneficial or detrimental impact on RD outputs and outcomes.

Nevertheless, there remains a serious gap in our understanding of the various dimensions of decentralization. The degree and different types of patterns of decentralization have not been described and measured in a consistent way across countries or over time, so that at best only an anecdotal characterization of the decentralization of $\mathrm{RD}$ and rural service delivery programs can be made. Without consistent description and measurement of the patterns of decentralization, it is not even possible to assess the issue of whether greater decentralization in some form is associated with greater success in RD and rural service delivery, or whether it results in better targeting of the poor and reduced poverty levels. Even less can one investigate issues of whether greater decentralization causes better RD outcomes.

\section{Conceptual Framework}

Cheema and Rondinelli (1983) recognized the importance of the political, fiscal and institutional elements of decentralization, but none of the authors explicitly related these three dimensions to RD outcomes. These outcomes can be defined in terms of: (i) effectiveness-providing minimum standards of service delivery costeffectively, and targeted toward disadvantaged groups; (ii) the responsiveness of decentralized institutions to the demands of local communities, at the same time as 
meeting the aims of broader public policy; and (iii) sustainability as indicated by political stability, fiscal adequacy and institutional flexibility. Factors that appear to have a positive impact on RD outcomes include: enhanced participation; greater resource mobilization; more institutional capacity-building; and increased accountability.

\section{Figure 1: Conceptual Model for Analyzing Decentralization}

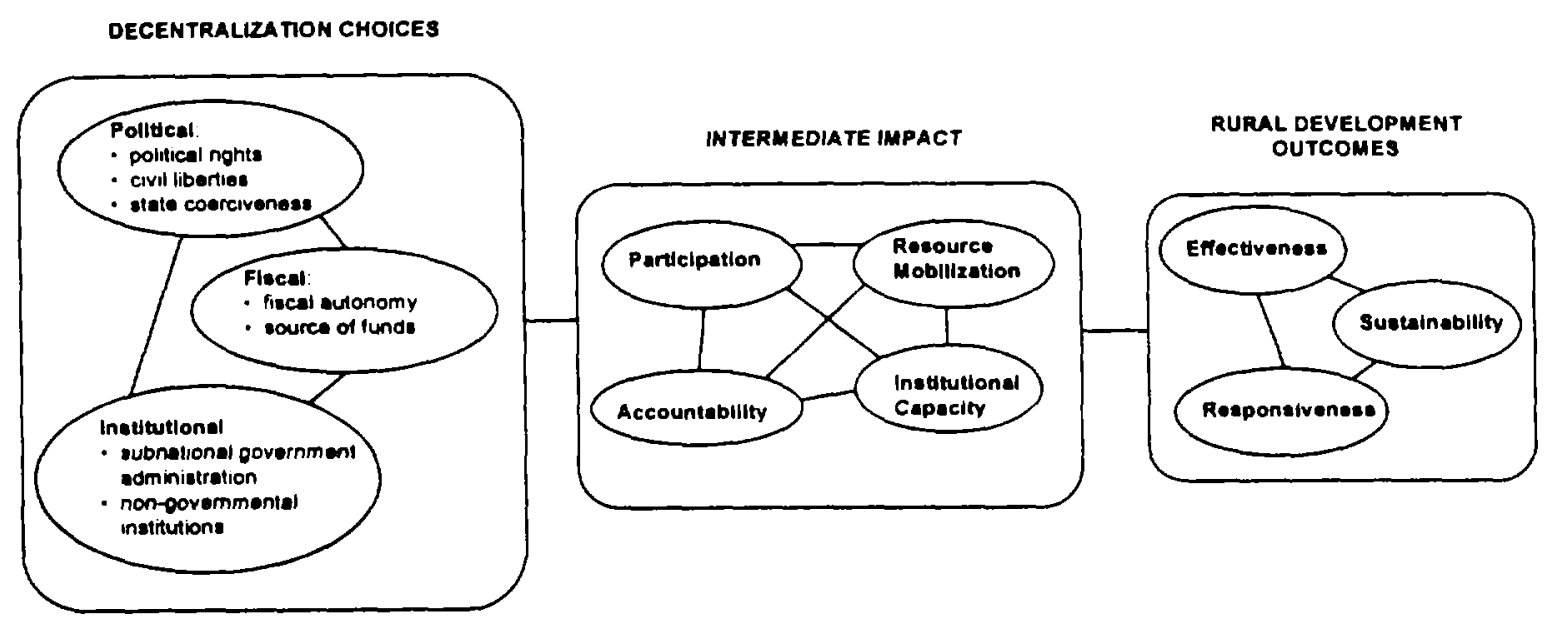

What becomes clear from the foregoing analysis is the need for a systematic approach to decentralization. Hard-and-fast rules are impossible to discern. Like a souffle that requires just the right combination of milk, eggs and heat to rise, so a successful program of decentralization will need to include just the right combination of political, fiscal and institutional elements.

This "soufflé theory of decentralization"11 attempts to bring together the dimensions of decentralization and relates them to a set of intermediate outcomes that are likely to have an important impact on overall RD outputs and outcomes (Figure 1). This simplified conceptual model provides a useful framework for analyzing the separate dimensions of decentralization and their interlinkages, and permits the investigation of patterns of decentralization across countries. This is an essential first step in developing a fuller characterization of the dimensions of decentralization. 


\section{Further Research}

Many of the general observations made in WB's 1974 policy document on RD remain true today, and a significant proportion of rural people continue to live in poverty. Past RD initiatives have not brought about the anticipated sustained improvement in the rural standard of living. However, rather than learning from mistakes and building on successes to formulate a new strategy for RD, there appears to be little debate on the appropriate design of $\mathrm{RD}$ policies, leaving a vacuum with no coherently defined policy on $\mathrm{RD}$. In particular, the failure to recognize the complexity associated with implementing programs of $\mathrm{RD}$ is likely to seriously compromise any attempt at rural poverty reduction.

There is, therefore, an urgent need for additional investigation to examine questions and issues that the literature on $\mathrm{RD}$ and decentralization has so far failed to address. Further research is needed to address the following issues raised in this paper:

- How can the important dimensions of decentralization be described and quantified? To develop characterizations to enable analysis of the fiscal, institutional and political arrangements that determine how rural public services are delivered in developing countries requires a review of: (i) government institutions and the formal and informal mechanisms that influence how they operate and (ii) non-government institutions (e.g., lineage-based groupings; associations; patron-client networks; communitybased groups; NGOs; political parties) and the mechanisms that influence how they operate. It will also be necessary to describe and analyze the interrelationships between government and non-government institutions.

- If, as is generally argued in the literature, decentralizing responsibilities will bring about a improvement in $\mathrm{RD}$ outputs and outcomes, why have governments adopted decentralized systems so rarely in practice? What are the underlying political, economic and social factors that influence the direction, pace and outcome of rural decentralization efforts? 
- What features of decentralized administrative, fiscal and political arrangements would help the poor derive greater benefits from rural development and reduce the capture of benefits by local elites? What features would assist in ensuring sustainable management of natural resources?

- How can measures of government-sponsored decentralization efforts and non-government institutional systems be used to quantify the impacts of various forms of decentralization on rural service delivery, rural growth and rural poverty?

- What are the determinants of the capacity of decentralized local government and non-government institutions to deliver rural public services? When and how can these two types of institutions act as complements or substitutes? Are special capacity-building programs required for either or both, and if so how should they be designed and financed?

- How can one account for differences among sectors associated with differences in service-delivery objectives and different sectoral outputs and technologies? How should the design of sector-specific institutions and programs reflect these differences?

- What are appropriate mechanisms for ensuring accountability of local government and non-government institutions to: (i) poor beneficiaries and local taxpayers and (ii) higher levels of government and international agencies? Available mechanisms include both formal financial controlscovering disbursement, auditing and procurement, and informal mechanisms, such as political and various community controls. What mixes of financial, political and community-based mechanisms allow for efficient local service delivery?

- What has been the role of donor policies and guidelines on procurement and disbursement of project funds in reinforcing centralizing tendencies and undermining attempts to decentralize financial authority in developing countries? 


\section{Notes:}

1 An IFAD study (Jazairy et al 1992) reported that more than one-third of the developing world's rural population lived below the poverty line in 1988 .

2 This review paper does not go into detail concerning the need to implement good macroeconomic policies. Binswanger (forthcoming) highlights the negative impact of poor macroeconomic policies on the design of agricultural and RD policies and programs.

3 Cross-country evidence on the correlation between various measures of government intervention in agriculture and agricultural as well as overall economic growth suggests that agricultural as well as economic growth were slowed down by government intervention in agriculture. There is substantial evidence for the large impact over time of depressing agricultural incentives on reducing agricultural investment and growth and increasing ruralurban migration; for a review, see Binswanger (1993).

4 Transfers out of agriculture averaged 46 percent of agricultural gross domestic product a year.

5 Some studies have provided positive evidence of the importance of spatial and product-wise concentration as a mechanism to obtain trade benefits (e.g., Amelung 1989).

6 This integrated approach to $\mathrm{RD}$ has a long history that predates the Bank's endorsement of it. In addition, during the $1970 \mathrm{~s}$ it was widely adopted by other aid agencies as the primary RD strategy.

7 Biggs (1984: 64) has observed that "feed-back systems between extension and research institutions are more evident as two-way arrows on an organizational chart in an office of the Ministry of Agriculture, rather than as senior scientists responding to reports coming from village level extension agents."

8 Of course, an effectively functioning democratic system requires the electoral process to be perceived as broadly free and fair, a major problem with local elections in Bangladesh in 1988, where widespread fraud led to the undermining of the Ershad regime (C\&M).

9 The capacity to borrow funds through financial markets is likely to be restricted to larger urban areas, and will be of little relevance to poor rural areas. In any case, the power to borrow independently is a function rarely granted to rural local governments. We therefore do not discuss this issue here.

10 Shah (1994) provides a detailed review of this literature, covering public choice theory and fiscal federalism.

1 I am grateful to Hans Binswanger for suggesting this apt analogy. 


\section{REFERENCES}

Amelung, T. 1989. "Determinants of Protection in Developing Countries: An Extended Interest-Group Approach" Kyklos 42: 4, 515-32

Bahl R.W. and Linn, J.F. 1992. Urban Public Finance in Developing Countries (New York: Oxford University Press)

Bates, R.H. 1983. "Patterns of Market Intervention in Agrarian Africa" Food Policy $8,297-304$

Becker, G.S. 1983. "A Theory of Competition Among Pressure Groups for Political Influence" Quarterly Journal of Economics 98: 3, 371-400

Becker, G.S. 1985. "Public Policies, Pressure Groups and Deadweight Costs" Journal of Public Economics 28, 329.47

Biggs, S. 1984. "Awkward but Common Themes in Agricultural Policy". In Clay and Schaffer $1984,59-74$

Binswanger, H.P. 1994. Agricultural and Rural Development: Painful Lessons Simon Brandt Address delivered at 32nd annual meeting of the Agricultural Economics Association of South Africa. Processed. (Washington DC: World Bank)

Binswanger, H.P. and Deininger, K. 1995. Towards a Political Economy of Agriculture and Agrarian Relations Processed. (Washington DC: World Bank)

Binswanger, H.P., Deininger, K. and Feder, G. 1993. Power, Distortions, Revolt and Reform in Agricultural Land Relations Policy Research Working Paper No. 1163 (Washington DC: World Bank)

Binswanger, H.P. and Rosenzweig, M.R. 1986. "Behavioral and Material Determinants of Production Relations in Agriculture" Journal of Development Studies 22, 503-39

Bird, R. and Wallich, C. 1993. Fiscal Decentralization and Intergovernmental Relations in Transition Economies: Toward a Systematic Framework of Analysis Policy Research Working Paper No. 1122 (Washington DC: World Bank)

Brock, W.A., Magee, S.P. and Young, L. 1989. Black Hole Tariffs and Endogenous Policy Theory: Political Economy in General Equilibrium (New York: Cambridge University Press)

Buchanan, J.M. and Tollison, R.D. 1984. The Theory of Public Choice - II (Ann Arbor: University of Michigan Press) 
Campbell, T., Peterson, G. and Brakarz, J. 1991. Decentralization to Local Government in LAC: National Strategies and Local Response in Planning, Spending and Management Latin America and the Caribbean Technical Department, Regional Studies Program, Report No. 5 (Washington DC: World Bank)

Cheema, G.S. and Rondinelli, D.A. eds. 1983. Decentralization and Development: Policy Implementation in Developing Countries (Beverly Hills: Sage)

Clay, E. and Schaffer, B. eds. 1984. Room for Manoeuvre: An Exploration of Public Policy Planning in Agricultural and Rural Development (London: Heinemann)

Cohen, S.S., Dyckman, J.W., Schoenberger, E., and Downs C.R. 1981. Decentralization: A Framework for Policy Analysis Project on Managing Decentralization (Berkeley: University of California)

Crook, R. and Manor. J. 1994. Enhancing Participation and Institutional Performance: Democratic Decentralization in South Asia and West Africa Overseas Development Administration, United Kingdom. Processed.

Dillinger, W. 1994. Decentralization and Its Implications for Urban Service Delivery Urban Management Programme Discussion Paper No. 16 (Washington DC: World Bank)

Feder, G. and Slade, R. 1986. "The Impact of Agricultural Extension: The Training and Visit System in India" World Bank Research Observer 1: 2, 139-161

Gardner, B.L. 1987. "Causes of U.S. Farm Commodity Programs" Journal of Political Economy 95: 2, 290-309

Grosh, M.E. 1994. Administering Targeted Social Programs in Latin America: From Platitudes to Practice World Bank Regional and Sectoral Study (Washington DC: World Bank)

Harris, R.L. "Centralization and Decentralization in Latin America". In Cheema and Rondinelli 1983, 183-202

Hayami, Y. and Anderson, K. 1986. The Political Economy of Agricultural Protection: East Asia in International Perspective (Boston: Allen and Unwin)

Hulme, D. 1992. "Enhancing Organizational Effectiveness in Developing Countries: The Training and Visit System Revisited" Public Administration and Development 12: 5, 433-445

Jaffee, S. and Srivastava, J. 1992. Seed System Development: The Appropriate Roles of the Private and Public Sectors World Bank Discussion Paper No. 167 (Washington DC: World Bank) 
Jazairy, I., Alamgir, M. and Panuccio, T. 1992. The State of World Rural Poverty: An Inquiry into Its Causes and Consequences (New York: New York University Press)

Johnston, B.F. and Southworth H.M. 1967. Agricultural Development and Economic Growth (Ithaca: Cornell University Press)

Krueger, A. 1974. "The Political Economy of the Rent-Seeking Society" American Economic Review 64, 3: 291-303

Lacroix, R. 1985. Integrated Rural Development in Latin America World Bank Staff Working Papers No. 716 (Washington DC: World Bank)

Lele, U. 1979. The Design of Rural Development: Lessons from Africa Third printing, with new postscript (Washington DC: World Bank)

Lewis, W.A. "Comment". In Johnston and Southworth 1967, 493-6

Lipton, M. 1977. Why Poor People Stay Poor: A Study of Urban Bias in World Development (Cambridge: Harvard University Press)

...... 1993. "Urban Bias: Of Consequences, Classes and Causality" Journal of Development Studies 29: 4, 229-58

Meenakshisundaram, S.S. 1994. Decentralisation in Developing Countries (New Delhi: Concept Publishing Company)

Nellis, J.R. 1983. "Decentralization in North Africa: Problems of Policy Implementation". In Cheema and Rondinelli 1983, 127-182

Olson, M. 1971. The Logic of Collective Action: Public Goods and the Theory of Groups (Cambridge, MA: Harvard University Press)

Olson, M. 1985. "Space, Agriculture and Organization" American Journal of Agricultural Economics 67, 928-37

Posner, R.A. 1975. "The Social Costs of Monopoly and Regulation" Journal of Political Economy 83, 4: 807-27

Putnam, R. 1993. Making Democracy Work (Princeton: Princeton University Press)

Rondinelli, D. 1981. "Government Decentralization in Comparative Perspective: Theory and Practice in Developing Countries" International Review of Administrative Science 47

Rondinelli, D.A. 1983. "Decentralization of Development Administration in East Africa". In Cheema and Rondinelli 1983, 77-125 
Ruttan, V. 1975. "Integrated Rural Development Programs: A Skeptical Perspective" International Development Review XVII, 4: 9-16

Ruttan, V. 1984. "Integrated Rural Development Programmes: A Historical Perspective" World Development 12, 393-401

Schiff, M. and Valdés, A. 1992. The Plundering of Agriculture in Developing Countries (Washington DC: World Bank)

Schmidt, G.D. 1989. Donors and Decentralization in Developing Countries: Insights from AID Experience in Peru (Boulder: Westview Press)

Shah, A. 1994. The Reform of Intergovernmental Fiscal Relations in Developing and Emerging Market Economies Policy and Research Series No. 23 (Washington DC: World Bank)

Shah. A. and Qureshi, Z. 1994. Intergovernmental Fiscal Relations in Indonesia: Issues and Reform Options World Bank Discussion Paper No. 239 (Washington DC: World Bank)

Smoke, P. 1992. "Rural Local Government Finance: The Case of Muranga'a County Council" Public Administration and Development 12, 87-96

Thirkildsen, O. 1994. Economic Decline and Democratic Decentralization in Rural Sub-Saharan Africa Paper presented at the Conference on Democratic Decentralization in Africa and Asia, September 21-23. Processed.

Tullock, G. 1984. "The Backward Society: Static Inefficiency, Rent Seeking, and the Rule of Law". In Buchanan and Tollison 1984, 224-237

Umali, D. 1992. Public and Private Sector Roles in Agricultural Research World Bank Discussion Paper No. 176 (Washington DC: World Bank)

Umali, D. and Schwartz, L. 1994. Public and Private Agricultural Extension: Beyond Traditional Frontiers World Bank Discussion Paper No. 236 (Washington DC: World Bank)

Umali, D., Feder, G. and de Haan, C. 1992. The Balance between Public and Private Sector Activities in the Delivery of Livestock Services World Bank Discussion Paper No. 163 (Washington DC: World Bank)

Varshney, A. 1993. “Introduction: Urban Bias in Perspective” Journal of Development Studies 29: 4, 3-22

Webster, N. 1990. Panchayati Raj and the Decentralization of Development Planning in West Bengal: A Case Study CDR Project Paper 90.7 (Copenhagen: Center for Development Research) 
Winkler, D. 1988. Decentraliztion in Education: An Economic Perspective Policy, Planning and Research Working Paper No.143 (Washington DC: World Bank)

Winkler, D. 1994. The Design and Administration of Intergovernmental Transfers: Fiscal Decentralization in Latin America World Bank Discussion Paper No. 235 (Washington DC: World Bank)

World Bank. 1974. Rural Development and Bank Policies: A Progress Report Agriculture and Rural Development Department, Report No. 588 (Washington DC: World Bank)

...... 1987. World Bank Experience with Rural Development Operations Evaluation Department, Report No. 6883 (Washington DC: World Bank)

...... 1993. New Lessons from Old Projects: The Workings of Rural Development in Northeast Brazil Operations Evaluation Department (Washington DC: World Bank)

…-. 1989. Decentralizing Revenues and the Provision of Services: A Review of Recent Experience Colombia, Report No. 7870-CO (Washington DC: World Bank)

….. 1990. Provincial Government Finances Argentina, World Bank Country Study (Washington DC: World Bank)

...... 1992a. Decentralization and Fiscal Issues Venezuela, Report No. 11160-VE, 2 volumes (Washington DC: World Bank)

-..-... 1992b. Subnational Government Finance Chile, Report No. 10580-CH (Washington DC: World Bank) 


\section{Pollcy Research Working Paper Serles}

\section{Title}

WPS1450 Social Safety Net and the Poor during the Transition: The Case of Bulgaria

WPS1451 Tunisia's Insurance Sector

WPS1452 The 1985-94 Global Real Estate
Cycle: Its Causes and Consequences

WPS1453 Air Pollution and Mortality: Results from Santiago, Chile

WPS1454 Child Labor: A Review

WPS1455 Tentative First Steps: An Assessment Bernard Hoekman of the Uruguay Round Agreement on Services

WPS1456 Equity Markets, Transaction Costs, and Capital Accumulation: An Illustration

WPS1457 Does Decentralization Increase Spending on Public Infrastructure?

WPS1458 Credit Policies: Lessons from East Asia

WPS1459 Pension Funds in Central Europe and Russia: Their Prospects and Potential Role in Corporate Govemment

WPS1460 Efficiency and Equity Considerations in Pricing and Allocating Irrigation Water

WPS1461 Stock Market Development and Firm Financing Choices

WPS1462 Stock Market Development and Financial Intermediaries

WPS1463 Rural Nonfarm Employment: A Survey Jean O. Lanjouw
Asli Demirgūç-Kunt Vojislav Maksimovic Asli Demirgūç-Kunt Ross Levine Peter Lanjouw

Contact

Date

for paper

May 1995

F. Smith

36072

May 1995

P. Infante

37642

May 1995

R. Gamer

37670

May 1995

C. Bernardo

37699

May 1995

May 1995

Valerie R. Bencivenga

May 1995

P. Sintim-Aboagye 38526

May 1995

May 1995

May 1995

Dimitri Vittas

Roland Michelitsch

Yacov Tsur

Ariel Dinar

May 1995

C. Spooner 32116

May 1995

May 1995

May 1995 85581
P. Sintim-Aboagye 38526

P. Sintim-Aboagye 38526

J. Shafer 


\section{Policy Research Working Paper Serles}

Thte

WPS1464 How Does the North American Free Trade Agreement Affect Central America?

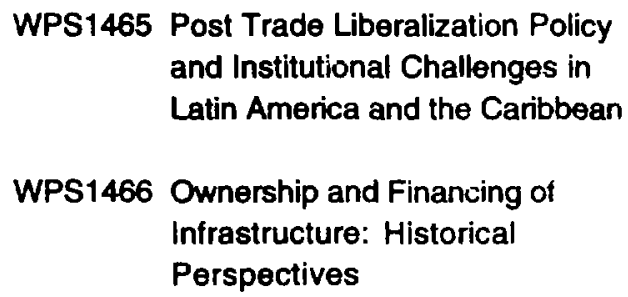

WPS1473 The Surge in Capital Inflows to Developing Countries: Prospects and Peter J. Montiel Policy Response

WPS1474 Are Stable Agreements for Sharing Intemational River Waters Now Possible?

WPS1475 Decentralization: The Way Forward for Rural Development?

\section{Date}

May 1995

May 1995

June 1995

June 1995

B. $\mathrm{Kim}$

82477

C. Anbiah

81275

WOR

31393

E. Khine

37471

June 1995

E. Khine

37471

June 1995

E. Khine

37471

D. Marc Kilgour

June 1995

C. Spooner 32116

Andrew N. Parker 